\title{
Evaluation of Implementation E-Government with Delone and Mclean
}

\author{
Evaluasi Implementasi E-Government dengan Pendekatan Model DeLone and McLean
}

Received:

27 June 2019

Revised:

24 October 2019

Accepted:

26 December 2019

\author{
${ }^{1 *}$ Erick Sorongan, ${ }^{2}$ Qory Hidayati \\ ${ }^{1,2}$ Teknik Elektronika, Politeknik Negeri Balikpapan \\ ${ }^{1,2}$ Balikpapan, Indonesia \\ E-mail: 'erick.sorongan@poltekba.ac.id, \\ ²ory.hidayati@poltekba.ac.id
}

*Corresponding Author

\begin{abstract}
This research intends to analyze and test variables that influence implementation Egovernment especially in Balikpapan city. The study uses the information system success model DeLone and McLean which has six main variables that can be used to measure the success rate of information systems. Many studies have proven the suitability of the model, so the writer will use it in this study. Variables that support the success of e-government that support this research include system quality and information quality as exogenous variables. Furthermore, the use and user satisfaction variables are endogenous variables that also affect the net benefits variable. Based on previous research, service quality variables have not been proven to affect endogenous variables, so the researchers omit these variables. Data collection is done by distributing questionnaires to users of e-government services in Balikpapan City as many as 100 respondents. Data processing methods with Structural Equation Modeling (SEM) using the Smart PLS 3.0 approach. This research proves the R-square value of the dependent variable user satisfaction is $62 \%$, and the net benefit variable is $59.1 \%$, which means that the dependent variable can be explained through independent variables in this research model. While the rest is explained by other variables outside the research model. Based on the findings in the study, it shows that the quality of the system has an effect on user satisfaction but has no impact on use.
\end{abstract}

Keywords-Information System, E-Government, Delone and Mclean, Evaluation

\begin{abstract}
Abstrak-Penelitian ini bertujuan untuk menganalisis dan menguji variabel-variabel yang mempengaruhi implementasi E-government khususnya di Kota Balikpapan. Studi menggunakan model kesuksesan sistem informasi DeLone dan McLean yang memiliki enam variabel utama yang bisa digunakan untuk mengukur tingkat keberhasilan sistem informasi. Banyak penelitian telah membuktikan kesesuaian model tersebut sehingga penulis akan menggunakannya dalam penelitian kali ini. Variabel yang yang diuji dalam penelitian antara lain kualitas sistem dan kualitas informasi sebagai variabel eksogen. Selanjutnya variabel use dan kepuasan pengguna sebagai variabel endogen yang sekaligus mempengaruhi variabel net benefits. Berdasarkan penelitian sebelumnya variabel kualitas layanan tidak terbukti berpengaruh terhadap variabel endogen sehingga penulis menghilangkan variabel tersebut. Pengumpulan data dilakukan dengan menyebarkan kuesioner kepada pengguna layanan e-government di Kota Balikpapan sebanyak 100 responden. Metode pengolahan data dilakukan dengan Structural Equation Modeling (SEM) menggunakan pendekatan Smart PLS 3.0. Hasil membuktikan nilai R-square variabel dependen kepuasan pengguna adalah sebesar $62 \%$ dan variabel net benefit 59,1\% yang artinya bahwa variabel dependen dapat dijelaskan melalui variabel independen dalam model penelitian ini. Sedangkan sisanya dijelaskan oleh variabel lain diluar model penelitian. Berdasarkan hasil temuan penelitian, menunjukkan kualitas sistem memberi pengaruh terhadap kepuasan pengguna namun tidak memiliki pengaruh terhadap penggunaan.
\end{abstract}

Kata Kunci-Sistem Informasi, E-Government, Delone, and Mclean, Evaluasi 


\section{INTRODUCTION}

Information Technology currently plays an essential role in e-government development efforts in the fulfillment of public services by using new methods that are more efficient and can prioritize the quality of the service itself. E-government as a whole becomes a platform for government management innovation, and the community becomes an alternative to get optimal public services. E-government is considered as the primary tool to facilitate citizens' access to various services, but the main challenge facing developing countries implementing Egovernment is the low level of service acceptance to the public [1]. The current condition of Balikpapan City's e-government is in the development phase of technology-based service innovations so as to improve the efficiency of bureaucratic performance. One-stop integrated service access implemented by the Balikpapan City Government through the Balikpapan.go.id website can help the community to find information about city government services. Existing services are divided into two main categories with each sub-service in it, the first is licensing services and the second is population services. SKPD services can be accessed using the web through the leading portal, although not all facilities are available and are only to direct each website to each department. The majority of web-based systems that are currently available are at the level of interaction using e-mail, whereas with the election of Balikpapan City to be one of 100 Smart Cities in Indonesia in 2019, it is time to improve services to the transaction stage.

The results of the study show that the challenge of developing industrial cities, especially the oil industry such as Balikpapan, is to anticipate changes in the era of the oil industry, which currently does not provide much benefit in terms of economic growth in society [2]. One form of anticipation that can be done is to transform public policies and regulations, where it can be realized into technology-based public services. If the transformation of public services is done in the right way, it will automatically increase public satisfaction as service users and encourage business investment through the creation of electronic transactions, such as e-procurement, where activities such as tenders, product catalogs, auctions and purchases are entirely based on automated systems. Currently, the City of Balikpapan has utilized e-government services both government-to-citizen and government-to-business, but the main problem is that there has never been a measurement of implementation evaluation that is able to investigate the success factors of e-government. This such evaluation is vital to know the real conditions and final expectations to be achieved so that if there is a gap, solutions and strategies can be easily found [3]. Balikpapan City Government will never know that e-government currently has run effectively before empirically carried out measurements using the right model. Based on the results of a brief observation, the services that are available up to this research can be said to still be web-based 
INTENSIF, Vol.4 No.1 February 2020

ISSN: 2580-409X (Print) / 2549-6824 (Online)

DOI: https://doi.org/10.29407/intensif.v4i1.13067

information (presence) where this is the lowest phase of e-government development while still requiring the public to come to the relevant agencies in administrative management because of the use of technology only limited to website usage. The next problem is that there are still many people who do not know that there are electronic services that can be used through the leading portal of the Balikpapan City Government website.

Based on the general problems above, if Balikpapan City Government is not severe in formulating the right strategy or policy, the final achievement of the implementation of the smart city will be increasingly difficult to realize. Ideally, the improvement strategy should also adjust from the results of a measurement of satisfaction level or based on factors that cause success and failure. Until now, many people have not utilized the IT-based services provided by the City Government of Balikpapan, even some people do not know about the existence of e-government services. Measurement by means of evaluation using an appropriate model has never been carried out on the implementation of e-government from the user side, so it is difficult to determine the initial strategic steps that need to be taken by Balikpapan City Government.

The success model of the information system was first introduced by DeLone and McLean in 1992 by showing the success of an information system can be represented by the quality characteristics of the system. DeLone and McLean [4] modified the model by following technological advances and also the needs of users. In the updated Information System Success model, there were three dependent variables namely information quality, system quality and service quality. Then the three dependent variables are intended to use, user satisfaction and net benefits. This model provides six variables that can help an organization or company implement an information system properly according to the expected end goal. This method of evaluation and use of models has proven conclusively in improving e-government services and local community democracy. Evaluation is done thoroughly about system suitability, system reliability, system security, system accuracy and expectations of users so that the system can continue to be used. This model is also able to provide an overview of the implementation of SI from the analysis result of the factors that influencing and inhibiting the success of the system.

Several studies used the success method of SI Delone and Mclean [5] to test the success of online public grievance redressal systems (OPGRS) in India, evaluated virtual education systems at one of the Universities in Iran with LISREL analysis [6], measuring e-government success od Pekalongan [7] and assessing the Indian Government UDISE by comparing studies between the success models of the original SI D\&M contained in Figure 1 and the updated model [8]. 


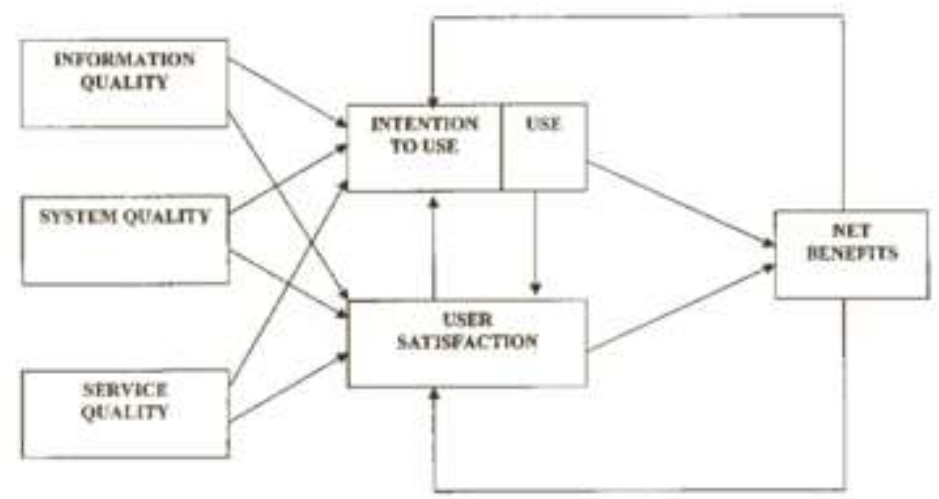

Figure 1. UPDATE D\&M IS SUCCESS MODEL

The purpose of this study is to evaluate the implementation of e-government in the Balikpapan Government by drawing closer to the side of user satisfaction and the use of technology-based services using the Delone and Mclean Information System Success Model. This research expects to analyze the factors that influence the success of e-government in Balikpapan and at the same time, become a recommendation for improvement, especially for services that are not felt to have a significant influence on society.

\section{RESEARCH METHOD}

The flow in this study begins by identifying the existing problems. Then proceed with the review of literature related to methods for solving problems and previous studies that have been done. The next step is to formulate a model and hypothesis, followed by compiling a questionnaire instrument that represents the constructor research variable. To prove the validity and reliability of all devices or research variables were tested by distributing questionnaires to respondents. The data is then tested using smart PLS software version 3 if the resulting value is under the rules or test parameters, the instrument is rearranged and the instrument under the parameter is removed. The next stage is to analyze data based on structural models to find out the significant level of constructs. The last step is to formulate conclusions based on the results of analysis and hypothesis testing. The following is the flow of research as shown in Figure 2. 
INTENSIF, Vol.4 No.1 February 2020

ISSN: 2580-409X (Print) / 2549-6824 (Online)

DOI: https://doi.org/10.29407/intensif.v4i1.13067

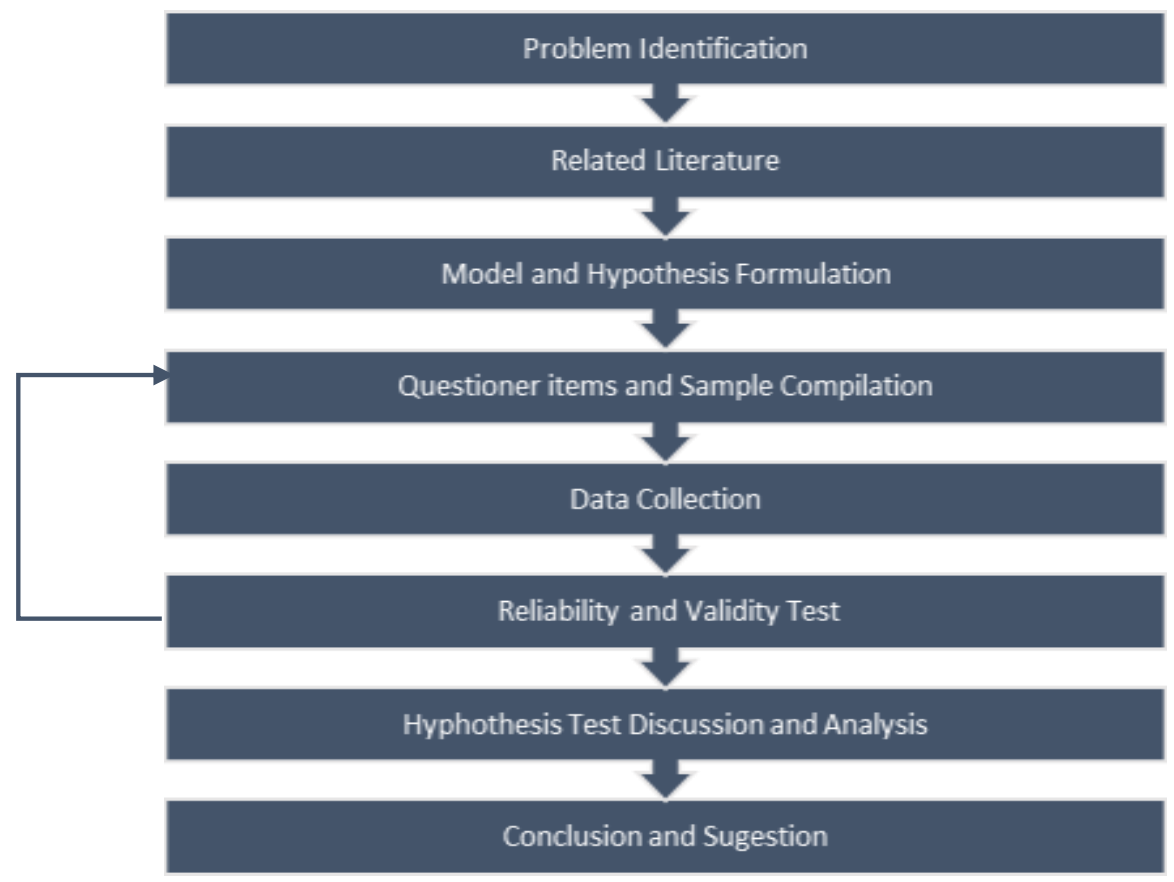

Figure 2. RESEARCH FLOW

In this study, researcher modified the D\&M model by using the use variable as the observed variable because some researchers [9], [10], [11] used the use variable as an outcome after going through a series of input variables that affected the result (one of the rejects the measure is use), while Delone and McLean [4] argued that this is because the measurement of using variables is not enough just to be measured by the amount of the system time using. So that a conclusion can be drawn that the use is measured through the feelings and attitudes of all the combined benefits a person receives from interacting with SI. In this condition, the variables that influence the success of information systems are the quality of information as the output of the system and the quality of the system itself. User satisfaction will ultimately have an impact on net benefits, so the framework is as follows:

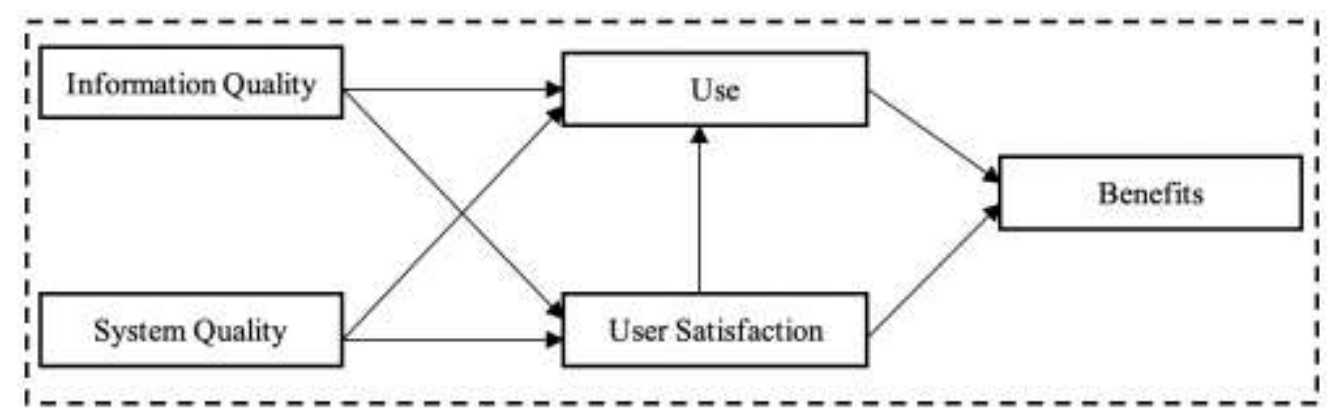

Figure 3. RESEARCH FRAMEWORK

Based on the framework and research model in figure 3 described previously, the research hypotheses are as follows:

H1: Information quality will positively influence usage 
$\mathrm{H} 2$ : Information Quality will positively affect user satisfaction

H3: The quality of the system will positively impact usage

H4: The quality of the system will positively affect user satisfaction

H5: Usage will positively affect net benefits

H6: User satisfaction will positively affect net benefits

H7: User satisfaction will positively influence usage

\section{A. Research Type}

This study is conclusive (causal) to investigate the effect of system quality and information quality for user satisfaction on e-government websites and their impact on net benefits for measuring e-government success with a public value approach.

\section{B. Research Variables}

Information quality can be interpreted as system output characteristics, such as content, reports and dashboards. There are six scales of measuring information quality, including completeness, precision, reliability, updated-data (currency), and the form of output (format of production) and relevance [5]. Previous studies have shown that information quality influences user usage and satisfaction [11], [12].

System Quality. As a measure of success, the quality of the system considers the technical aspects of the system, including access convenience, system functionality, reliability, response time, sophistication, ease of navigation, and flexibility. This variable is used to measure the desired characteristics of the system [13]. Previous studies have shown that system quality has an influence on user satisfaction [11], [14].

Use. As mentioned above that use is not measured by a questionnaire. The variables about these dimensions are all taken from secondary data. It was stated that there are various ways and actions that were tried to capture the use of SI; it has the potential to cause mixed results between use and other construction in the D\&M model.

User satisfaction is the individual's perception of the level of satisfaction with the system against the initial expectations of individuals using the system. Previous studies have shown that user satisfaction has an influence on usage [13], [15].

Net Benefits. Scott et al. [16] proposed a unique and essential adaptation of the information system success model [4] for the government context. By combining concepts from public administration and e-government research, they built a comprehensive model of the net benefits of public values from the perspective of citizens. They propose that the use of public value (use) to measure effectiveness, efficiency, and social value improvement based on the DeLone and McLean models [4] creates a balanced success model, designed for the public sector. 
INTENSIF, Vol.4 No.1 February 2020

ISSN: 2580-409X (Print) / 2549-6824 (Online)

DOI: https://doi.org/10.29407/intensif.v4i1.13067

\section{Questionnaire Compilation}

The questionnaire used in this study serves as a tool to get primary data. The research questionnaire was arranged based on the indicators that make up the research variables in the form of closed questions. Questions of the dimensions of system success adopt the information system success model DeLone and McLean [4]. Whereas issues of e-government success adopt a public value approach to net benefits proposed by Scott [16]. Full research indicators can be seen in Table 1.

Table 1. RESEARCH QUESTIONNAIRE

\begin{tabular}{|c|c|c|}
\hline Variable & Code & "Question \\
\hline \multirow{3}{*}{ System Quality } & SQ1 & $\begin{array}{l}\text { This e-government website is accompanied by instructions so that it } \\
\text { can be easily used }\end{array}$ \\
\hline & SQ2 & $\begin{array}{l}\text { This e-government website has an attractive interface and useful } \\
\text { features }\end{array}$ \\
\hline & SQ3 & $\begin{array}{l}\text { I get convenience through this website when going to do work } \\
\text { because it is supported by a fast service in responding to complaints / } \\
\text { problems }\end{array}$ \\
\hline \multirow{5}{*}{$\begin{array}{l}\text { Information Quality- } \\
\text { Resources }\end{array}$} & IQ1 & The information provided by this website meets my needs \\
\hline & IQ2 & Through this website, I get the information I need in time \\
\hline & IQ3 & Information provided by this website is accurate \\
\hline & IQ4 & The information provided by this website is up to date \\
\hline & IQ5 & The information provided by this website is clear \\
\hline \multirow{4}{*}{ User Satisfaction } & US1 & I find it easy and quick to adjust to using this website \\
\hline & US2 & I feel compelled to use this website \\
\hline & & back when one day you need public services \\
\hline & US3 & Overall I am satisfied with this public service electronic system \\
\hline \multirow{2}{*}{$\begin{array}{l}\text { Net Benefits- Good } \\
\text { Information Source } \\
\text { (Scott et al.) [16] }\end{array}$} & NB1 & This website increases my understanding of city problems \\
\hline & NB2 & $\begin{array}{l}\text { This website allows me to build knowledge about issues that are } \\
\text { important to me }\end{array}$ \\
\hline \multirow{4}{*}{$\begin{array}{l}\text { Net Benefits-Trust } \\
\text { Resources (Scott et } \\
\text { al.) }[16]\end{array}$} & NB3 & $\begin{array}{l}\text { I feel that this website is acting in the interest of the citizens of } \\
\text { Balikpapan }\end{array}$ \\
\hline & NB4 & $\begin{array}{l}\text { I feel comfortable interacting with this website because it generally } \\
\text { fulfills its duties efficiently }\end{array}$ \\
\hline & NB5 & $\begin{array}{l}\text { I feel confident that this website can be counted on to do its work } \\
\text { when interacting }\end{array}$ \\
\hline & NB6 & $\begin{array}{l}\text { I feel comfortable relying on this website when fulfilling its } \\
\text { obligations }\end{array}$ \\
\hline
\end{tabular}


INTENSIF, Vol.4 No. 1 February 2020

ISSN: 2580-409X (Print) / 2549-6824 (Online)

DOI: https://doi.org/10.29407/intensif.v4i1.13067

\section{Data Analysis}

\section{Validity test}

A validity test is used to determine the validity of the measurement instruments used in research. Testing is done by correlating item scores with total scores. Convergent validity is related to the principle that the meters of a construct should be highly correlated [17]. Convergent validity tests on reflective indicators can be seen from the loading factor value for each construct indicator [18]. The rule of thumb of convergent validity parameters can be seen in Table 2.

Table 2. CONVERGENT VALIDITY TEST PARAMETERS

\begin{tabular}{|c|c|c|}
\hline Validity Test & Parameters & Practical Rules \\
\hline Convergen & Loading factor & $\begin{array}{l}\text { a. }>0,70 \text { for confirmatory } \\
\text { research } \\
\text { b. }>0,60 \text { for exploratory } \\
\text { research }\end{array}$ \\
\hline & $\begin{array}{l}\text { Average Variance } \\
\text { Extracted }(A V E)\end{array}$ & $\begin{array}{l}>0,50 \text { for confirmatory and } \\
\text { exploratory research }\end{array}$ \\
\hline & Communality & $\begin{array}{l}>0,50 \text { for confirmatory and } \\
\text { exploratory research }\end{array}$ \\
\hline
\end{tabular}

An indicator of questions will be considered valid if it has a correlation value above 0.70 [18]. But for loading values, 0.50 to 0.60 can be accepted by looking at the output correlation between the latent variable and the indicator questions. In this study, the values above are 0.60.

\section{Reliability Test}

The reliability test is used to test the consistency of the measuring instrument against the symptoms measured at different times with the same symptoms. Reliability testing can be done with Cronbach's alpha test and composite reliability. In this study, the reliability testing method will use the composite reliability test to ensure the instrument is free from random errors, as did previous researchers [19], [13]. The practical rule of the reliability test parameters can be seen in Table 3.

Table 3. Reliability TEST PARAMETERS

\begin{tabular}{cl}
\hline \hline \multicolumn{1}{c}{ Parameters } & \multicolumn{1}{c}{ Practical Rules } \\
\hline Composite Reliability & a. $>0,70$ for confirmatory research \\
& b. $0,60-0,70$ is still acceptable for exploratory research
\end{tabular}

Structural Model (Inner Model)

INTENSIF: Jurnal Ilmiah Penelitian dan Penerapan Teknologi Sistem Informasi 
INTENSIF, Vol.4 No.1 February 2020

ISSN: 2580-409X (Print) / 2549-6824 (Online)

DOI: https://doi.org/10.29407/intensif.v4i1.13067

Evaluation of structural models aims to predict relationships between variables. structural models are used to test causality (hypothesis testing). In PLS, the structural model of the study was evaluated using $\mathrm{R}^{2}$ (R-square) for the dependent variable, the path coefficient, or t-values for each path for testing the significance of the constructs [17]. The higher the R-square value means the better the predictive power of the proposed research model. The R-square amount produced by PLS shows the number of variants of the construct explained by the research model [18].

\section{RESULT AND DISCUSSION}

\section{A. Data Analysis}

The questionnaire was distributed to 100 respondents consisting of 6 city districts in Balikpapan, and the technique used to test the relationship in the construction of the model is a structural equation model (SEM) which can be seen in Figure 4, where the application used is Smart PLS version 3.2.8 which runs on the Mac OS operating system. This application has a function to display flow diagrams and data analysis topics with the aim of describing egovernment website user data.

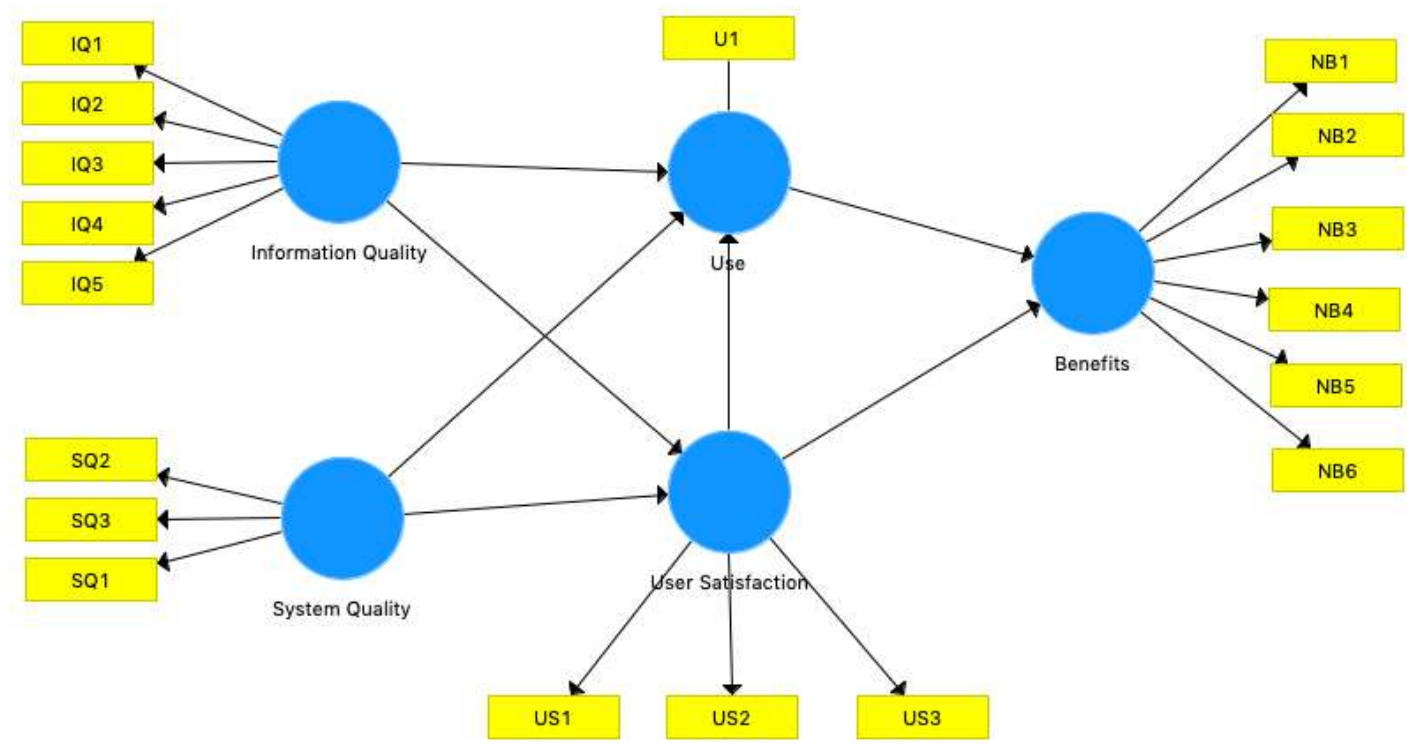

Figure 4. SMART Pls DiAgRAM 
INTENSIF, Vol.4 No.1 February 2020

ISSN: 2580-409X (Print) / 2549-6824 (Online)

DOI: https://doi.org/10.29407/intensif.v4i1.13067

\section{B. Characteristics of Respondents}

Table 4. CHARACTERISTIC OF RESPONDENTS

\begin{tabular}{cccc}
\hline \hline Characteristic & Description & Amount & Percentage \\
\hline Gender & Male & 60 & $60 \%$ \\
Age & Female & 40 & $40 \%$ \\
& $<20$ Years old & 56 & $56 \%$ \\
& $21-30$ Years old & 36 & $36 \%$ \\
& $31-40$ Years old & 5 & $5 \%$ \\
& $41-50$ Years old & 2 & $2 \%$ \\
\hline \multirow{3}{*}{ Education } & S2 & 2 & $2 \%$ \\
& D4/S1 & 20 & $20 \%$ \\
& D3 & 47 & $47 \%$ \\
& SMA/SMK & 31 & $31 \%$ \\
\hline Domisili District & North Balikpapan & 46 & $46 \%$ \\
& South Balikpapan & 12 & $12 \%$ \\
& West Balikpapan & 13 & $13 \%$ \\
& East Balikpapan & 11 & $11 \%$ \\
& Central Balikpapan & 8 & $8 \%$ \\
& Balikpapan City & 10 & $10 \%$ \\
\hline
\end{tabular}

In the characteristics respondents table 4 , the total number of respondents is 100 people, where this is the ideal number recommended at least 10 times the amount of independent variables [17]. This research itself consists of 5 variables, namely 2 independent variables and 3 dependent variables. The characteristics of respondents consisted of $60 \%$ men and $40 \%$ women. Based on the percentage of age at most age $<20$ years amount 56\%, ages 21-30 years amount $36 \%, 31-40$ years amount $5 \%$, and the remaining ages $41-50$ years amount $2 \%$. Based on the level of education at most D3 amounts, 47\%, SMA / SMK amount 31\%, D4 / S1 amount 20\%, and S2 amount 2\%. According to the characteristics of the respondents' domiciles in this study, most of the districts are North Balikpapan 46\%, West Balikpapan 13\%, South Balikpapan 12\%, East Balikpapan 11\%, Balikpapan City 10\% and Central Balikpapan 8\%. At the characteristics of respondents as in Table 4, according to the level of education, it can be said that respondents who filled out the questionnaire had the ability to use internet-based information technology so that the data used in this study was feasible to use. 
INTENSIF, Vol.4 No.1 February 2020

ISSN: 2580-409X (Print) / 2549-6824 (Online)

DOI: https://doi.org/10.29407/intensif.v4i1.13067

\section{Convergent Validity Test}

Validity tests intended to determine the suitability and adequacy of the questions raised in the questionnaire to be the basis for research. In this study, the loading factor threshold value used was 0.60 . If the loading factor of the indicator is more than 0.60 , then the indicator is declared valid. Table 5. shows the loading factor value of each indicator.

Table 5. LOADING FACTOR CALCULATION

\begin{tabular}{cccccc}
\hline \hline & Benefits & $\begin{array}{c}\text { Information } \\
\text { Quality }\end{array}$ & $\begin{array}{c}\text { System } \\
\text { Quality }\end{array}$ & Use & $\begin{array}{c}\text { User } \\
\text { Satisfaction }\end{array}$ \\
\hline IQ1 & 0 & 0,764 & 0 & 0 & 0 \\
\hline IQ2 & 0 & 0,819 & 0 & 0 & 0 \\
\hline IQ3 & 0 & 0,794 & 0 & 0 & 0 \\
\hline IQ4 & 0 & 0,793 & 0 & 0 & 0 \\
\hline IQ5 & 0 & 0,709 & 0 & 0 & 0 \\
\hline NB1 & 0,788 & 0 & 0 & 0 & 0 \\
\hline NB2 & 0,753 & 0 & 0 & 0 & 0 \\
\hline NB3 & 0,812 & 0 & 0 & 0 & 0 \\
\hline NB4 & 0,741 & 0 & 0 & 0 & 0 \\
\hline NB5 & 0,702 & 0 & 0 & 0 & 0 \\
\hline NB6 & 0,830 & 0 & 0 & 0 & 0 \\
\hline SQ1 & 0 & 0 & 0,695 & 0 & 0 \\
\hline SQ2 & 0 & 0 & 0,745 & 0 & 0 \\
\hline SQ3 & 0 & 0 & 0,815 & 0 & 0 \\
\hline U1 & 0 & 0 & 0 & 1,000 & 0 \\
\hline US1 & 0 & 0 & 0 & 0 & 0,723 \\
\hline US2 & 0 & 0 & 0 & 0 & 0,790 \\
\hline US3 & 0 & 0 & 0 & 0 & 0,812 \\
\hline
\end{tabular}

The next convergent validity test is to examine the AVE and the communality value of the constructs that compose the research model. Table 6. shows that the AVE value and communality of all constructs are more significant than 0.50 so that all constructs are declared to meet the requirements of convergent validity. 
INTENSIF, Vol.4 No.1 February 2020

ISSN: 2580-409X (Print) / 2549-6824 (Online)

DOI: https://doi.org/10.29407/intensif.v4i1.13067

Table 6. AVE AND COMMUNALITY VALUE

\begin{tabular}{ccc}
\hline \hline & Communality & Average Variance Extracted (AVE) \\
\hline Benefits & 0,597 & 0,597 \\
\hline Information Quality & 0,603 & 0,603 \\
\hline System Quality & 0,567 & 0,567 \\
\hline Use & 1,000 & 1,000 \\
\hline User Satisfaction & 0,602 & 0,602 \\
\hline
\end{tabular}

\section{Discriminant Validity Test}

Discriminant validity is related to the principle that different constructors' gauges should not be highly correlated. Discriminant validity test is assessed based on cross-loadings measurements with the constructor can also compare the roots of AVE for each construct with the correlation between constructs with other constructs in the research model

Table 7. CROSS LOADING VALUE OF RESEARCH MODEL

\begin{tabular}{|c|c|c|c|c|c|}
\hline & $\begin{array}{c}\text { Information } \\
\text { Quality }\end{array}$ & Benefits & $\begin{array}{l}\text { System } \\
\text { Quality }\end{array}$ & $\overline{\text { Use }}$ & $\begin{array}{c}\text { User } \\
\text { Satisfaction }\end{array}$ \\
\hline IQ1 & 0,764 & 0,576 & 0,582 & $-0,038$ & 0,673 \\
\hline IQ2 & $\mathbf{0 , 8 1 9}$ & 0,469 & 0,491 & 0,159 & 0,515 \\
\hline IQ3 & 0,794 & 0,371 & 0,431 & 0,194 & 0,495 \\
\hline IQ4 & 0,793 & 0,463 & 0,473 & 0,178 & 0,524 \\
\hline IQ5 & 0,709 & 0,494 & 0,455 & 0,004 & 0,562 \\
\hline NB1 & 0,531 & 0,788 & 0,562 & 0,017 & 0,637 \\
\hline NB2 & 0,389 & 0,753 & 0,424 & $-0,088$ & 0,568 \\
\hline NB3 & 0,525 & $\mathbf{0 , 8 1 2}$ & 0,628 & $-0,005$ & 0,682 \\
\hline NB4 & 0,504 & 0,741 & 0,573 & 0,138 & 0,536 \\
\hline NB5 & 0,409 & 0,702 & 0,396 & 0,005 & 0,512 \\
\hline NB6 & 0,497 & $\mathbf{0 , 8 3 0}$ & 0,521 & 0,008 & 0,598 \\
\hline SQ1 & 0,455 & 0,511 & 0,695 & 0,079 & 0,446 \\
\hline SQ2 & 0,433 & 0,378 & 0,745 & 0,030 & 0,495 \\
\hline SQ3 & 0,536 & 0,622 & $\mathbf{0 , 8 1 5}$ & $-0,099$ & 0,620 \\
\hline U1 & 0,120 & 0,015 & $-0,010$ & 1,000 & $-0,040$ \\
\hline US1 & 0,518 & 0,500 & 0,463 & 0,119 & 0,723 \\
\hline US2 & 0,441 & 0,635 & 0,506 & $-0,076$ & 0,790 \\
\hline US3 & 0,698 & 0,640 & 0,640 & $-0,107$ & $\mathbf{0 , 8 1 2}$ \\
\hline
\end{tabular}


INTENSIF, Vol.4 No.1 February 2020

ISSN: 2580-409X (Print) / 2549-6824 (Online)

DOI: https://doi.org/10.29407/intensif.v4i1.13067

In Table 7., the value of cross-loading correlations between constructs and their indicators is higher than the correlation values between indicators and other constructs. This is in accordance with the principle of discriminant validity so that all indicators are declared to meet the discriminant validity requirements in cross-loadings testing.

\section{E. Reliability Test}

This study uses composite reliability with a minimum value of 0.60 because it is an exploratory study. In Table 8., it shows that all variables produce composite reliability values > 0.60 so that it can be concluded that all indicators of this research variable meet the reliability test

Table 8. Composite Reliability Value

\begin{tabular}{cc}
\hline \hline & $\begin{array}{c}\text { Composite } \\
\text { Reliability }\end{array}$ \\
\hline Benefits & 0,898 \\
\hline $\begin{array}{c}\text { Information } \\
\text { Quality }\end{array}$ & 0,884 \\
\hline System Quality & 0,796 \\
\hline Use & 1,000 \\
\hline User Satisfaction & 0,819 \\
\hline
\end{tabular}

\section{F. Research Hypothesis Test Results}

This research conducted 7 hypotheses available in this model, 3 hypotheses were rejected, and 4 hypotheses were accepted. To test the relationship of hypotheses can be done by comparing the value of T-statistics with T-table values, while the coefficient $(\beta)$ of the independent variable to the dependent variable (positive or negative) can be seen in the path coefficient. This study uses a T-table (significance) for 95\% confidence $(\alpha=0.05)$, which is 1.96. If the T-table value is smaller than 1.96, the hypothesis is rejected. For H1 in this study it was found that information quality affects usage (with a T-statistic value of 2.324), for H2 it was found that information quality affected user satisfaction (with a T-statistic 6.357), whereas for $\mathrm{H} 3$, it was found that the quality of the system was not in accordance with user satisfaction. For H4, it was found that the quality of the system affected user satisfaction (with a T-statistic of 6.046), whereas for H5, it was found that use did not affect the benefits (with a T-statistic of 0.698). For H6, it was found that user satisfaction affected benefits (with a T-statistic 12,281), while for $\mathrm{H} 7$, it was found that user satisfaction did not use (with a T-statistic 1,635). 
INTENSIF, Vol.4 No.1 February 2020

ISSN: 2580-409X (Print) / 2549-6824 (Online)

DOI: https://doi.org/10.29407/intensif.v4i1.13067

Table 9. HyPOTHESIS TEST RESUlTS

\begin{tabular}{|c|c|c|c|c|}
\hline Hypothesis & $\begin{array}{c}\text { Sample } \\
\text { Mean (M) }\end{array}$ & $\begin{array}{c}\text { Standard Deviation } \\
\text { (STDEV) }\end{array}$ & $\begin{array}{c}\text { T Statistics } \\
(|\mathrm{O} / \mathrm{STDEV}|)\end{array}$ & $\overline{\text { Result }}$ \\
\hline $\begin{array}{c}\text { Information } \\
\text { Quality -> Use }\end{array}$ & 0,331 & 0,139 & 2,324 & Accepted \\
\hline $\begin{array}{c}\text { Information } \\
\text { Quality -> } \\
\text { User } \\
\text { Satisfaction }\end{array}$ & 0,482 & 0,073 & 6,357 & Accepted \\
\hline $\begin{array}{c}\text { System Quality } \\
\text {-> Use }\end{array}$ & $-0,040$ & 0,136 & 0,332 & Rejected \\
\hline $\begin{array}{c}\text { System Quality } \\
\text {-> User } \\
\text { Satisfaction }\end{array}$ & 0,404 & 0,067 & 6,046 & Accepted \\
\hline Use -> Benefits & 0,046 & 0,066 & 0,698 & Rejected \\
\hline $\begin{array}{c}\text { User } \\
\text { Satisfaction -> } \\
\text { Benefits }\end{array}$ & 0,773 & 0,063 & 12,281 & Accepted \\
\hline $\begin{array}{c}\text { User } \\
\text { Satisfaction -> } \\
\text { Use }\end{array}$ & $-0,253$ & 0,148 & 1,635 & Rejected \\
\hline
\end{tabular}

\section{CONCLUSSION}

Based on the research conducted, the results prove that from a total of 7 hypotheses, 4 hypotheses have a positive impact, and 3 hypotheses do not have a positive effect, the quality of the system has an influence on user satisfaction but does not have a control on usage. It can be concluded that e-government website users do not feel the quality of the system because the services contained in the system are not implemented optimally. Next is user satisfaction has an effect. There are net benefits but use does not have an impact on net benefits, which can be concluded that it takes ease in using the system so that users can quickly adapt and want to use it again. Based on the conclusions, the researcher suggests implementing the City of Balikpapan e-government development to add service features to the transactional stage so as to increase user interest in utilizing integrated services through the website. Subsequent research needs to 
INTENSIF, Vol.4 No.1 February 2020

ISSN: 2580-409X (Print) / 2549-6824 (Online)

DOI: https://doi.org/10.29407/intensif.v4i1.13067

be done by adding independent variables outside the research model so that specifically, it is able to increase the use of the system.

\section{AKNOWLEGMENT}

The researcher would like to thank the Kemenristekdikti for funding this research through the Beginner Lecturer DRPM research scheme 2019. Furthermore, thanks also to the Research and Service Center of the Balikpapan State Polytechnic Community for providing the opportunity to the researcher to participate in the selection of proposals so that this research can be carried out with well.

\section{REFERENCE}

[1] M. A. Sarrayrih and B. Sriram, "Major challenges in developing successful egovernment: A review on the Sultanate of Oman," J. King Saud Univ. - Comput. Inf. Sci., vol. 27, no. 2, pp. 230-235, 2015.

[2] A. K. M. Tarigan, D. A. A. Samsura, S. Sagala, and R. Wimbardana, "Balikpapan: Urban planning and development in anticipation of the post-oil industry era," JCIT, vol. 60, pp. 246-259, 2017.

[3] S. Lee-geiller and T. David, "Using government websites to enhance democratic Egovernance : A conceptual model for evaluation," Gov. Inf. Q., vol. 36, no. 2, pp. 208225, 2019.

[4] S. Petter, W. Delone, and E. R. McLean, "Information systems success: The quest for the independent variables," J. Manag. Inf. Syst., vol. 29, no. 4, pp. 7-61, 2013.

[5] N. P. Rana, Y. K. Dwivedi, M. D. Williams, and V. Weerakkody, "Investigating success of an e-government initiative: Validation of an integrated IS success model," Inf. Syst. Front., vol. 17, no. 1, pp. 127-142, 2014.

[6] Z. Mahmoodi et al., "The evaluation of a virtual education system based on the DeLone and McLean model: A path analysis," F1000Research, vol. 6, p. 1631, 2017.

[7] P. H. Saputro, A. D. Budiyanto, and A. J. Santoso, "Model Delone and Mclean Untuk Mengukur Kesuksesan E-government Kota Pekalongan,” Sci. J. Informatics, vol. 2, no. 1, pp. 1-8, 2015.

[8] S. S. Sirsat and M. S. Sirsat, "A Validation of The Delone And Mclean Model On The Educational Information System Of The Maharashtra State ( India )," Int. J. Educ. Learn. Syst., vol. 1, pp. 9-18, 2016.

[9] M. T. Thielsch, S. M. Meeßen, and G. Hertel, "Trust and distrust in information systems at the workplace," PeerJ, pp. 1-26, 2018.

[10] M. Karlinsky-Shichor, Yael; Zviran, "Factors Influencing Perceived Benefits and User Satisfaction in Knowledge Management Systems," Inf. Syst. Manag., vol. 33, no. 1, pp. 55-73, 2016.

[11] H. Mohammadi, "Computers in Human Behavior Investigating users ' perspectives on elearning: An integration of TAM and IS success model," Comput. Human Behav., vol. 45, pp. 359-374, 2015.

[12] G. A. A. Wisudiawan, "Analisis Faktor kesuksesan Sistem informasi menggunakan model delone and McLean," J. Ilm. Teknol. Inf. Terap., vol. 2, no. 1, pp. 55-59, 2015.

[13] M. N. Yakubu and S. I. Dasuki, "Assessing eLearning systems success in Nigeria: an application of the DeLone and McLean Information Systems Success Model," J. Inf. 
Technol. Educ. Res., vol. 17, pp. 183-203, 2018.

[14] B. Tilahun and F. Fritz, "Modeling antecedents of electronic medical record system implementation success in low-resource setting hospitals," BMC Med. Inform. Decis. Mak., vol. 15, no. 61, pp. 1-9, 2015.

[15] L. Alzahrani, W. Al-karaghouli, and V. Weerakkody, "Investigating the impact of citizens ' trust toward the successful adoption of e-government: A multigroup analysis of gender, age, and internet experience," Inf. Syst. Manag., vol. 35, no. 2, pp. 124-146, 2018.

[16] M. Scott, W. DeLone, and W. Golden, "Measuring eGovernment success: a public value approach," Eur. J. Inf. Syst., vol. 25, no. 3, pp. 187-208, May 2015.

[17] J. F. Hair, G. T. M. Hult, S. M. Ringle, and M. Sarstedt, A primer on partial least squares structural equation modeling (PLS-SEM), 2nd ed. Los Angeles: SAGE Publications, Inc., 2017.

[18] I. Ghozali and H. Latan, Partial Least Squares Konsep, Teknik dan Aplikasi Menggunakan Program Smart PLS 3.0 untuk Penelitian Empiris, 2nd ed. Semarang: Universitas Diponegoro Semarang, 2014.

[19] R. Govindaraju, I. I. Wiratmadja, and A. Haryana, "Pengembangan Model Evaluasi Kualitas Layanan Sistem E-Government,” J. Manaj. Teknol., vol. 15, no. 2, pp. 196-205, 2016. 